\title{
Motivation in Physical Education and Foreign Language Learning in CLIL Teaching: Gender Differences and Implications for Future Studies
}

\author{
ELISEO FERnÁndEZ BarRionUEVO \\ I.E.S. La Zafra, Motril \\ Antonio BaEna Extremera \\ Universidad de Murcia
}

Received: 27 March, 2016 / Accepted: 18 May 2018

ISSN: 1697-7467

\begin{abstract}
The goal of this paper is to show the differences between girls and boys in how FLL (Foreign Language Learning), and PE (Physical Education) is perceived in CLIL (Content and Language Integrated Learning) contexts. In this study, based on a t-student analysis, significant differences by sex were found in Intrinsic Motivation-Knowledge and Accomplishment for FLL, Amotivation for PE, and Satisfaction/Boredom for PE and FLL. This would justify a future line of work, also developed in this article, as well as its future contributions.
\end{abstract}

Keywords: CLIL, motivation, self-determination, physical education, foreign language learning.

Motivación en educación física y el aprendizaje de la lengua extranjera en enseñanza AICLE: Diferencias por género e implicaciones para estudios futuros

RESUMEN: La finalidad de este artículo es mostrar las diferencias entre chichas y chicos en cuanto a su percepción del aprendizaje de la lengua extranjera (LE) y la educación física (EF) en contextos AICLE (Aprendizaje Integrado de Contenidos y Lengua Extranjera). En este estudio, basado en un análisis T-student, se han hallado diferencias significativas entre sexos en las variables de motivación intrínseca al conocimiento y al logro para FLL, amotivación en la Educación Física y Satisfación/Aburrimiento para Educación Física y FLL. Esto justificaría futuras líneas de investigación, sugeridas en el artículo, así como también sus posibles futuras contribuciones.

Palabras clave: AICLE, motivación, autodeterminación, educación física, aprendizaje de la lengua extranjera.

\section{INTRODUCTION}

"From the very beginning, the fire of CLIL has been fuelled from various sides: highlevel policy and grass-root actions" (Dalton-Puffer, Nikula, \& Smit, 2010:4). Nowadays, this methodology is widely spread all over Europe to the extent that most countries implement it in some of their schools (Eurydice, 2008). Therefore, more research is needed in order to obtain the necessary data that support not only educational policy but the teaching practice. 
In Spain, and particularly in Andalucía, the Plurilingualism Promotion Plan (Plan de Fomento del Plurilingüismo; Acuerdo de 22 de marzo de 2005 del Consejo de Gobierno, por el que se aprueba el Plan de Fomento del Plurilingüismo en Andalucía) meant a turning point in the linguistic policy of this region. As a result, currently there are 641 secondary bilingual schools in English (Averroes, 2015).

The implementation of CLIL methodology in the last few years has allowed for some research to be made on its integration effects in Andalucía. One study about the practical aspects of the Plurilingualism Promotion Plan set in this region reached, among other conclusions, that the students of the bilingual branches acquire a higher linguistic FL (Foreign Language) competence level, compared to non-CLIL pupils, without finding any differences in the communication skills and/or the key competences. A high or very high level of satisfaction among all the participants as well as the need for training of coordinators and teachers were also highlighted (Coral \& Lleixá, 2013; Lorenzo, Casal, \& Moore, 2009).

Another study with a qualitative methodology developed by Cabezas-Cabello (2010) enquired into the strengths and weaknesses in the implementation of CLIL programmes, concluding that, despite the cognitive, affective and intellectual benefits, there are basic linguistic and methodological loopholes in the teaching of non-linguistic curricular subjects and the school coordination, together with an excessive ambition in the linguistic policies, which lack in milestones or clear guidelines.

Nevertheless, as Pérez-Cañado (2011) states, the specificity of the field and the need to connect the theory with the teaching after some time from its introduction may justify more research about different topics like the affective factors. This would help to offer scientific evidence transferable to the didactic and the educational policy that would ease some of the formerly mentioned weaknesses.

\section{INTEGRATED TEACHING OF PHYSICAL EDUCATION AND A FOREIGN LANGUAGE}

The role these subjects play in the different educational systems varies according to their organizational requirements, the status of the subject or the approach of the bilingual programme. Based on totally different educational contexts, we point out three examples where the integrated teaching of PE and a FL or a L2 (Second Language) is used with different goals.

In the schools managed by the European Union, PE is used to introduce a second language as this is considered a "cognitively less demanding and context-embedded" subject (Skutnabb-Kangas \& Dunbar, 2010). In this way, PE is used as a tool for an additive bilingualism instead of a subtractive one.

On the other side, PE has been used with other purposes, such as the one mentioned in a study by McCall (2011) that took place in the UK, where the integrated teaching of football and French was used to motivate male students. This author concludes that the inclusion of an interesting and relevant topic of daily life positively affects the language learning attitude.

In the Secondary Education schools of Andalusia that offer bilingual education, at least two non-linguistic subjects should be taught using Spanish and a FL as vehicular languages, the learning of content being the basic element over language proficiency (Orden de 28 de junio de 2011 por la que se regula la enseanza bilingüe en los centros docentes de la 
Comunidad Autónoma de Andalucía). This leads the schools to be responsible, according to organizational and pedagogical criteria, for selecting the subjects to be taught through a FL.

In that field, where school administrators and public officials share the responsibility of deciding which subjects will belong to the bilingual project, it is necessary to analyse how the various subjects interact with the FL when taught in an integrated way. Therefore, the inclusion of a certain non-linguistic subject in a bilingual project would be justified not only for organizational reasons, but also according to pedagogical criteria, so that the selection of a specific area will seek a concrete objective, such as increasing the motivation towards foreign languages or introducing the FL, as it is a less demanding cognitive and content embedded subject.

\section{Motivation in CLIL, PE and FL}

"It is a student's desire to understand and use the content that motivates him or her to learn the language" (Coyle, Hood, \& Marsh, 2010:11). In this context, one of the authors of the book had previously stated: "One of the most powerful findings of CLIL groups centres on increased motivation in both learners and teachers" (Coyle, 2006:11).

In this connection, a number of studies prove that CLIL has positive effects on several aspects of motivation in different contexts. Some examples worth mentioning are the studies of Lasagabaster (2011) in the Basque Country, Seikkula-Leino (2007) in Finland, Mearns (2012) and Hunt (2011) in England, and Hewit and García-Sánchez (2012) in the Almeria Province (Spain). In any case, the present study aims to go beyond those analyses, not only because motivation is addressed in a global way in CLIL settings, but also because the interaction of a non-linguistic subject with a FL will be examined using the framework of the self-determination theory (Deci \& Ryan, 1985, 2000).

In the field of PE, there is ample evidence that links the self-determined motivation with factors such as the enjoyment of the exercises (Granero-Gallegos, Baena-Extremera, Pérez-Quero, Ortíz-Camacho, \& Bracho-Amador, 2012), the cooperative learning and positive motivational consequences: interest, satisfaction and high participation (Baena-Extremera, Gómez-López, Granero-Gallegos, 2017; Baena-Extremera, Gómez-López, Granero-Gallegos, \& Ortiz-Camacho, 2014; Wang \& Biddle, 2001), the importance of PE and the intention to partake in leisure-time physical activity (Granero-Gallegos, Baena-Extremera, Pérez-Quero, Ortiz-Camacho, \& Bracho-Amador, 2014; Moreno-Murcia, Huescar, \& Cervello, 2012).

As for the learning of a FL, Intrinsic Motivation has been positively linked to self-confidence (Pae, 2008), the performance in the FL course (Morales-Rodríguez, 2011), the intention to continue with the FL studies, or, conversely, with the reduction of anxiety levels (Noels, Clement, \& Pelletier, 1999; Noels, Pelletier, Clément, \& Vallerand, 2000).

The self-determination theory has been used as a basis for separate research in CLIL, $\mathrm{PE}$ and LE research. Taking those studies as a baseline, we intend to determine if there is a transfer in motivational types in CLIL. As a first step, we begin this study by analysing whether there are sex differences in FLL and PE motivation, in order that future research will be be able to deepen the understanding of the antecedent and outcomes of this motivational transfer. 


\section{STUdy}

\subsection{Participants}

A total of 150 students of bilingual Physical Education in English from one secondary education school of one medium-sized Andalusian city $(60,000$ inhabitants) participated in this study ( 72 boys $=48 \%, 78$ girls $=52 \%)$. Their ages ranged between 12 and 16 years $(\mathrm{M}=13.47, \mathrm{SD}=1.30)$, mean age of the boys 13.43 years $(\mathrm{SD}=1.29)$, and of the girls 13.50 $(\mathrm{SD}=1.38)$. All the students took part voluntarily.

Distribution by course was as follows: $45(30 \%)$ studied first grade of Compulsory Secondary Education (CSE); 36 (24\%), were in second grade of CSE; 36 (24\%), were in third grade of CSE; $15(10 \%)$, were fourth graders of CSE; and $18(12 \%)$ were in their first year of high school.

\subsection{Instruments}

Four scales have been selected, two of them are designed for Physical Education (SMS and SSI) while the other two measure similar variables but in the context of the Foreign Language (LLOS-IEA and an adaptation of the ISC).

\subsubsection{Language Learning Orientation Scale (LLOS-IEA)}

A translation and adaption of the scale designed by Noels et al. (2000) has been used. It is based on the "Academic Motivation Scale", developed by Vallerand, Blais, Brière, \& Pelletier (1989), and originally adapted and translated into English by Vallerand et al. (1992). This instrument assesses the "Amotivation", the three types of Intrinsic Motivation - "Knowledge", "Mastery" and "Stimulation"-, and the three types of extrinsic motivation - "External Regulation", "Introjected Regulation" and "Identified Regulation". This scale includes three items for each of its seven factors, where the respondents indicate the extent to which they agree with each item using a 7-point Likert scale.

\subsubsection{Spanish version of the "Sport Motivation Scale (SMS)" adapted to Physical Education}

Based on the Spanish version of the SMS, Balaguer, Castillo, and Duda (2007), Granero-Gallegos, Baena-Extremera (2013) developed a new scale in the context of PE. This scale, originally known as Échelle de Motivation dans les Sports (ÉMS) (Brière, Vallerand, Blais, \& Pelletier, 1995), was renamed as Sport Motivation Scale (SMS) (Pelletier et al., 1995) when it was translated into English. This version includes the same 7 factors of the LLOS-IEA scale but adapted to PE instead of the FL learning: "Amotivation", the three types of Intrinsic Motivation: "Knowledge", "Mastery" and "Stimulation", and the three types of extrinsic motivation: "External Regulation", "Introjected Regulation" and "Identified Regulation". They also have in common that the answers use a polytomous item scale with a score range between 1 (absolutely disagree) and 7 (absolutely agree). However, unlike the SMS there are three items per factor. 
E. Fernández Barrionuevo and A. Baena Extremera Motivation in Physical Education and Foreign...

\subsubsection{Spanish version of the Sport Satisfaction Instrument (SSI) adapted to Physical Education}

The Spanish version of the Sport Satisfaction Instrument (SSI) adapted to Physical Education (Baena-Extremera, Graneros-Gallegos, Bracho-Amador, \& Pérez-Quero, 2012), the items of which are based on the version of SSI (Balaguer, Atienza, Castillo, MorenoMurcia, \& Duda, 1997). Originally, this scale was designed by Duda and Nicholls (1992) on the basis of the Intrinsic Satisfaction Classroom Scale (ISC) (Nicholls, Cheung, Lauer, \& Patashnick, 1989) for the school context. This five-level Liker instrument includes two factors: "Satisfaction/Enjoyment" and "Boredom", with five items for the former and two for the latter.

\subsubsection{Intrinsic Satisfaction Classroom Scale (ISC) adapted for the FL learning.}

The Spanish version of the ISC (Castillo, Balaguer, \& Duda, 2001) adapted for the FL learning. This instrument, as is the case with SSI, includes the factors "Satisfaction/ Enjoyment" $(\alpha=.815)$ and "Boredom" $(\alpha=.774)$.

\subsection{Procedure}

Permission was obtained from the school administrators to perform this investigation. The students were informed of the purpose of the study and of their rights as participants. The questionnaires were administered in a hall, in groups of more than forty students. Each participant took up to 40 minutes to complete the questionnaires. The responses were anonymous. The procedure followed the principles from the Declaration of Helsinki (2008).

\subsection{Data analysis}

Preliminary data analyses and descriptive statistics were performed before testing the hypotheses. First, a confirmatory factor analysis (CFA) was conducted to examine the construct validity of the variables in the study and the Cronbach Alpha coefficient was used to calculate the reliability of the instruments adapted.

A t-student analysis was conducted, and the mean value (M) and standard deviation (SD) calculation was performed to determine if there were differences by sex in the analysis of each of the factors, and between the factors for PE and their equivalents in FLL. The Levene statistic and the effect size were also calculated.

\section{RESUlts}

Regarding reliability, not all the variables exceed .70 (Table 1). Therefore, we could have considered that the reliability of the variables under .70 is not acceptable (Nunnally, 1967; Nunnally and Bernstein,1994). However, as we assume this study is a preliminary 
phase of a bigger investigation, values of .50 or .60 would be enough (Nunnally, 1967:226). All the factors with Cronbach Alpha under .50 were dismissed for this study and should be accounted for future research.

Table 1. Cronbach a of the factors

\begin{tabular}{|c|c|c|}
\hline Questionnaire & Variable & Alpha \\
\hline LLOS-IEA & Amotivation & $\alpha=.714$ \\
\hline \multirow[t]{6}{*}{$(F L L)$} & External Regulation & $\alpha=.480$ \\
\hline & Identified Regulation & $\alpha=.730$ \\
\hline & Introjected Regulation & $\alpha=.475$ \\
\hline & Intrinsic Motivation-Knowledge & $\alpha=.686$ \\
\hline & Intrinsic Motivation-Stimulation & $\alpha=.846$ \\
\hline & Intrinsic Motivation-Accomplishment & $\alpha=.809$ \\
\hline \multirow[t]{7}{*}{$\operatorname{SMS}(P E)$} & Amotivation & $\alpha=.655$ \\
\hline & External Regulation & $\alpha=.571$ \\
\hline & Identified Regulation & $\alpha=.688$ \\
\hline & Introjected Regulation & $\alpha=.538$ \\
\hline & Intrinsic Motivation-Knowledge & $\alpha=.734$ \\
\hline & Intrinsic Motivation-Stimulation & $\alpha=.706$ \\
\hline & Intrinsic Motivation-Accomplishment & $\alpha=.807$ \\
\hline \multirow[t]{2}{*}{$\operatorname{ISC}(F L L)$} & Satisfaction/enjoyment & $\alpha=.815$ \\
\hline & Boredom & $\alpha=.774$ \\
\hline \multirow[t]{2}{*}{ SSI $(P E)$} & Satisfaction/enjoyment & $\alpha=.875$ \\
\hline & Boredom & $\alpha=.759$ \\
\hline
\end{tabular}

With respect to t-student conducted, (table 2) significant differences by sex were found showing that girls had higher values in Intrinsic Motivation-Knowledge and Intrinsic Motivation-Accomplishment both for FLL, Amotivation for PE and Satisfaction/Enjoyment for FLL. On the contrary values of Satisfaction/Enjoyment for PE in boys are higher. Nevertheless, the effects sizes in all variables are small. 
E. Fernández Barrionuevo and A. Baena Extremera Motivation in Physical Education and Foreign...

Table 2: Mean values, standard deviation and t-student analysis.

\begin{tabular}{|c|c|c|c|c|c|c|c|c|}
\hline $\begin{array}{l}\text { Quest- } \\
\text { ionnaire }\end{array}$ & Variable & $\operatorname{Sex}$ & $M$ & $S D$ & $\begin{array}{l}\text { Lev- } \\
\text { ene }\end{array}$ & $t$ & $\begin{array}{l}\text { Tstu- } \\
\text { dent } \\
\text { (Sig.) }\end{array}$ & $\begin{array}{l}\text { Effect } \\
\text { size }\end{array}$ \\
\hline \multirow{12}{*}{$\begin{array}{l}\text { LLOS-IEA } \\
(\text { FLL) }\end{array}$} & \multirow{2}{*}{ Amotivation } & Male & 1.588 & 1.112 & .120 & \multirow{2}{*}{.953} & \multirow[t]{2}{*}{.342} & \multirow[t]{2}{*}{.629} \\
\hline & & Female & .892 & 1.101 & & & & \\
\hline & \multirow{2}{*}{ External Regulation } & Male & 5.287 & 1.078 & .407 & \multirow{2}{*}{.804} & \multirow[t]{2}{*}{.423} & \multirow[t]{2}{*}{.131} \\
\hline & & Female & 5.141 & 1.140 & & & & \\
\hline & \multirow{2}{*}{$\begin{array}{l}\text { Identified } \\
\text { Regulation }\end{array}$} & Male & 5.500 & 1.334 & .270 & \multirow{2}{*}{-.598} & \multirow[t]{2}{*}{.551} & \multirow[t]{2}{*}{-.097} \\
\hline & & Female & 5.632 & 1.376 & & & & \\
\hline & \multirow{2}{*}{$\begin{array}{l}\text { Introjected } \\
\text { Regulation }\end{array}$} & Male & 3.620 & 1.460 & .613 & \multirow{2}{*}{-1.823} & \multirow[t]{2}{*}{.070} & \multirow[t]{2}{*}{-.297} \\
\hline & & Female & 4.042 & 1.377 & & & & \\
\hline & \multirow{2}{*}{$\begin{array}{l}\text { Intrinsic Motiva- } \\
\text { tion-Knowledge }\end{array}$} & Male & 4.615 & 1.310 & .827 & \multirow{2}{*}{-2.007} & \multirow[t]{2}{*}{.047} & \multirow[t]{2}{*}{-.328} \\
\hline & & Female & 5.038 & 1.267 & & & & \\
\hline & \multirow{2}{*}{$\begin{array}{l}\text { Intrinsic Motiva- } \\
\text { tion-Stimulation }\end{array}$} & Male & 4.500 & 1.413 & .460 & \multirow{2}{*}{-1.789} & \multirow[t]{2}{*}{.076} & \multirow[t]{2}{*}{-.292} \\
\hline & & Female & 4.927 & 1.504 & & & & \\
\hline & \multirow{2}{*}{$\begin{array}{l}\text { Intrinsic Motivation- } \\
\text { Accomplishment }\end{array}$} & Male & 4.791 & 1.481 & .573 & 2507 & .010 & -.423 \\
\hline & & Female & 5.388 & 1.334 & & -2.591 & & \\
\hline & Amotivation & Male & 1.864 & 1.146 & .059 & 2435 & .016 & -.399 \\
\hline & Amotration & Female & 2.362 & 1.339 & & $-2.7 J J$ & & \\
\hline & Fyternal Reoulation & Male & 4.246 & 1.471 & .768 & $255-2>3>$ & .394 & .139 \\
\hline & External Keguiation & Female & 4.038 & 1.506 & & . 855 & & \\
\hline & Identified & Male & 4.902 & 1.250 & .345 & 106 & .916 & .017 \\
\hline & Regulation & Female & 4.881 & 1.219 & & .100 & & \\
\hline SMS (PF) & Introjected & Male & 5.451 & 1.175 & .629 & 437 & .663 & .071 \\
\hline SIVIS (FL) & Regulation & Female & 5.371 & 1.056 & & .451 & & \\
\hline & Intrinsic Motivation- & Male & 5.184 & 1.310 & .469 & -778 & .438 & -.126 \\
\hline & Knowledge & Female & 5.346 & 1.242 & & & & \\
\hline & Intrinsic Motivation- & Male & 5.479 & 1.210 & .650 & 182 & .855 & .030 \\
\hline & Stimulation & Female & 5.445 & 1.036 & & .183 & & \\
\hline & Intrinsic Motivation- & Male & 5.569 & 1.312 & .238 & 243 & .216 & -.201 \\
\hline & Accomplishment & Female & 5.810 & 1.062 & & & & \\
\hline & Satisfaction/ & Male & 3.297 & .863 & .897 & -2470 & .015 & -.403 \\
\hline ISC $(\mathrm{PE})$ & & Female & 3.641 & .840 & & & & \\
\hline $1 \mathrm{NC}(1 \mathrm{~L})$ & Boredom & Male & 2.243 & 1.044 & .048 & 67 & .887 & .0241 \\
\hline & Doredom & Female & 2.217 & 1.109 & & $-2.46 /$ & & \\
\hline & Satisfaction/ & Male & 4.452 & .785 & .234 & 979 & .050 & .324 \\
\hline SSI (FI ) & enjoyment & Female & 4.176 & .910 & & 1.919 & & \\
\hline SNI (ILL) & Boredom & Male & 1.838 & .952 & .915 & -053 & .958 & -.008 \\
\hline & & Female & 1.846 & .946 & & -.005 & & \\
\hline
\end{tabular}




\section{Discussion}

The aim of this paper is to know if there is a transfer in motivational types in CLIL, due to the difficulties involved (Valero \& Jiménez-Fernández, 2015). Thus, regarding gender differences, the manner students are motivated through PE and FLL shows a totally opposed pattern of behaviour. Even though not all the results are significant, the mean values of all the types of Intrinsic Motivation and Extrinsic Motivation (except for Intrinsic Motivation-Stimulation) are higher for boys whereas, inversely, the scores are higher for girls in FLL. On the other hand, amotivation presents opposite results, being higher for boys in FLL and for girls in FLL.

In line with these scores, the mean values of Satisfaction/Enjoyment in PE and Boredom in FLL are greater for boys, whilst for girls they are higher for Satisfaction/Enjoyment in FLL and Boredom in PE.

While (Kirk, 2003) assures PE as it is nowadays is a masculinised form of the subject, Williams, Burden, and Lanvers (2002) describes the feminine bias in FLL due to social or familiar factors, or even to a fewer male language teachers. This sexualized concept of both domains could be in the bottom line of the gender discrepancies.

In relation to the above stated, from a practical perspective, two different strategies could be undertaken to achieve a more balanced scenario in the field of bilingual PE: First, teachers should find the strategies to empower the less motivating part of the PE in CLIL: FLL for girls and the PE itself for boys.

A second approach would be to increase the motivation in FLL in boys by adding something enjoyable (PE) to the boring factor (FLL). Conversely, PE motivation in girls could be enhanced by introducing some language learning in it.

As there is evidence in this and other studies (McCall 2011) that boys and girls perceive PE and FLL differently, we consider that future investigations should examine the origin of those differences and the relationship between factors related to PE and FLL. In order to be more specific, we reckon that forthcoming research in this field should have the following objectives:

1. To predict, in a CLIL context, the transfer of motivational factors related to the self-determination theory from the student perception of PE to the LE learning perception.

2. To predict the effect of factors related to PE teaching on that transfer.

3. To predict the effect of that transfer on factors related to FL learning.

In the next section we will justify these objectives by developing the contributions and implications of future investigations into the school organizational, pedagogical, epistemological and fields.

\section{CONTRIBUTIONS OF THE FUTURE STUDIES}

Many of the studies carried out in the CLIL field analyse affective and motivational factors, but they do not focus on the effect of one single non-linguistic subject in the FL and vice-versa. However, references about how integrated learning affects the linguistic 
proficiency (Lasagabaster, 2008; Lorenzo et al., 2009), and the content learning (Campo, Grisaleña, \& Alonso, 2007; Jäppinen, 2005) can be found.

Each school course varies in its connotation or even its methodology. Therefore, it is reasonable to believe that, since the school work integrates FL and content aspects, both factors would influence the student's motivation. As a consequence, studying History, Mathematics or PE through a foreign language would motivate each student differently according to the concept he/she has of the subject itself or its methodology. Therefore, "some learners who have a more negative attitude towards either the content subject or the language may have greater motivation towards the other subject and through this may improve their attitude toward the less-liked element" (Coyle et al., 2010:89).

This forthcoming research brings a new perspective because, apart from enabling an analysis of the CLIL motivation from a global standpoint, a single non-linguistic subject focus is also developed. Therefore, the integrated learning motivation may vary depending on whether the content belongs to Science, Social Studies or PE.

\subsection{Educational policy implications}

In this new scenario, "content and language learning are so closely intertwined that no line can be drawn between content learning and language development" (Lorenzo, 2007:34). And, to be able to adapt themselves to the new learning environment, the educational administrations will have to make decisions. Therefore, in order to optimise this methodology more information about the integration of the FL and each of the subjects is needed.

Besides, not all the subjects are equally suitable for integration. For instance, in the European Union Schools, bilingual teaching starts through "content-embedded subjects" such as $\mathrm{PE}$ and, years later, continues with "decontextualized verbally and intellectually demanding subjects" (Skutnabb-Kangas \& McCarty, 2008). Some Swedish bilingual programs also consider that each subject has its own benefits, and they tend to include one subject from the following groups: "social studies", "aesthetic subjects", "science", and "sports" (Eurydice, 2006a). In Holland, with the goal of addressing a variety of registers and styles, Social Studies, Science and Creative subjects (including PE) are included (Eurydice, 2006b). Even some dual models in the United States acknowledge the unique nature of the special subjects, recommending an integrated learning in L2 apart from L1 with the goal of providing an equal status for both languages (Howard, Sugarman, Christian, Lindhom-Leary, \& Rogers, 2007).

The empirical knowledge of the benefits and peculiarities of the FL and PE integration will allow to determine the most appropriate channel to introduce this subject and the specific objective it should have. This research, centred in the attitudinal and affective factors of this integration, would be included in the frame that Pérez-Cañado (2012) suggests for future research, and will contribute to the development of the CLIL programmes: "Largescale investigations of this nature will provide additional relevant research findings about the effects of CLIL instructional practices which will contribute to the sustainability and future development of dual-focused programs" (Pérez-Cañado, 2012:332). 


\subsection{Pedagogical implications}

Apart from supporting institutional decisions, the data resulting from this study will help teachers in their work. In the course of a lesson, the motivational and other attitudinal factors are essential for the student learning: "Without sufficient motivation, even individuals with the most remarkable abilities cannot accomplish long term goals, and neither are appropriate curricula and good teaching enough on their own to ensure student motivation" (Dalton-Puffer, 2011:191).

Therefore, so as to increase the willingness to communicate in the classroom, CLIL teachers should be aware of the factors affecting the student motivation. In this respect, Coyle et al. (2010:42) state: "teachers' knowledge of the affective side of their learners is vital in their own understanding of how to determine both the task styles and outcomes which will inspire learners and also the degree of scaffolding needed to support their learning".

Apart from analyzing the "affective factors transference" between PE and FL, future studies should analyse some teaching aspects such as the "teacher communication competence", or the "student perception of communicative barriers", among others. We assume that, ultimately, those variables would have a positive influence in the self-determined FLL and PE motivation.

\subsection{Epistemological implications}

Referring to future research, Coyle (2007:558) points out that one of the ways of keeping the scientific community connected would be: "uniting a much wider field of research that is associated with language learning per se, including learning theories, language learning theories, intercultural and social processes and provides a lens through which integrated learning can be interpreted".

This study broadens the CLIL research approach by considering motivational factors originated in other fields, such as the self-determination theory. Pérez-Cañado (2012) indicates that the attitudinal and affective factors should be predominantly present in the research agendas.

Another innovative element of this research is that, for the study of any affective CLIL aspect, the particular characteristics of both FL and PE should be taken into consideration. That does not mean that we refuse to accept that integration occurs, but we believe that factors related to the content and the language would individually affect it. As a part of this approach, Dalton-Puffer (2011:196) states:

Concerns with theorizing the interaction of language and content are currently becoming a focus of attention for CLIL researchers. Although the most frequently used wording tends to be that of "content and language integration," a more appropriate goal, I think, would be to transcend such an understanding that conceptualizes language and curricular content as separate reified entities and instead think of them as one process. 
E. Fernández Barrionuevo and A. Baena Extremera Motivation in Physical Education and Foreign...

\section{REFERENCES}

Acuerdo de 22 de marzo de 2005 del Consejo de Gobierno, por el que se aprueba el Plan de Fomento del Plurilingüismo en Andalucía. (B.O.J.A., Nº5 del 5 de abril de 2005).

Averroes (2015). Buscador de proyectos en los centros docentes. Consejería de Educación. Junta de Andalucía, http://www.juntadeandalucia.es/educacion/portalaverroes, accessed 15 November 2016.

Baena-Extremera, A., \& Granero-Gallegos, A. (2015). Versión española del Sport Satisfaction Instrument (SSI) adaptado al aprendizaje de la Educación Física bilingüe en Inglés. Porta Linguarum, 24, 63-76, available from http://www.ugr.es/ portalin/, accessed 15 November, 2016.

Baena-Extremera, A., Gómez-López, M., Granero-Gallegos, A. (2017). Aprendizje de la Educación Física bilingüe a partir de las metas de logro y el clima de aprendizaje. Porta Linguarum, 28, 81-93, available from http://www.ugr.es/ portalin/, accessed 15 February, 2018.

Baena-Extremera, A., Gómez-López, M., Granero-Gallegos, A., \& Ortiz-Camacho, M. M. (2014). Predicting Satisfaction in Physical Education from Motivational Climate and Self-determined Motivation. Journal of Teaching in Physical Education, 34, 210-224.

Baena-Extremera, A., Graneros-Gallegos, A., Bracho-Amador, C., \& Pérez-Quero, F. J. (2012). Versión española del Sport Satisfaction Instrument (SSI) adaptado a la Educación Física. Revista de Psicodidáctica, 17(2), 377-396.

Balaguer, I., Atienza, F. L., Castillo, I., Moreno-Murcia, Y., \& Duda, J. L. (1997). Factorial structure of measures of satisfaction/interest in sport and classroom in the case of Spanish adolescents. Paper presented at the Abstracts of 4th European Conference of Psychological Assesment, Lisbon.

Balaguer, I., Castillo, I., \& Duda, J. L. (2007). Propiedades psicométricas de la escala de motivación en deportistas españoles. Revista Mexicana de Psicología, 24(2), 197-207.

Brière, N. M., Vallerand, R. J., Blais, M. R., \& Pelletier, L. G. (1995). Développement et validation d'une mesure de motivation intrinsèque, extrinsèque et d'amotivation en contexte sportif: 1‘Échelle de motivation dans les sports (ÉMS). International Journal of Sport Psychology, 26, 465-489.

Cabezas-Cabello, J. (2010). A SWOT analysis of the Andalusian Plurilingualism Promotion Plan (APPP). In P. C. M. L. (Ed.), Proceedings of the 23rd GRETA Convention. Jaen: Joxman.

Campo, A., Grisaleña, J., \& Alonso, E. (2007). Alumnado trilingüe en secundaria: una nueva realidad". Instituto vasco de evaluacin e investigacin educativa Bilbao iseiivei. Bilbao: isei.ivei.

Castillo, I., Balaguer, I., \& Duda, J. L. (2001). Perspectivas de meta de los adolescentes en el contexto académico. Psicothema, 13(1), 79-86.

Coral, J. \& Lleixá, T. (2013). Las tareas en el aprendizaje integrado de educación física y lengua extranjera (ACICLE). Determinación de las características de las tareas mediante análisis del diario de clase. Retos. Nuevas tendencias en Educación Física, Deporte y Recreación, 24, 79-84.

Coyle, D. (2006). Content and language integrated learning: Motivating learners and teachers. Scottish Languages Reviews, 13, 1-18.

Coyle, D. (2007). Content and language integrated learning: towards a connected research agenda for CLIL pedagogies. International journal of bilingal education and bilingualism, 10, 543-562.

Coyle, D., Hood, P., \& Marsh, D. (2010). CLIL Content and Language Integrated Learning. Cambridge: Cambridge University Press. 
Dalton-Puffer, C. (2011). Content-and-Language Integrated Learning: From Practice to Principles?. Annual Review of Applied Linguistics, 31(1), 182-204.

Dalton-Puffer, C., Nikula, T., \& Smit, U. (2010). Charting policies, premises and research on content and language integrated learning. In C. Dalton-Puffer, T. Nikula \& U. Smit (Eds.), Language Use and Language Learning in CLIL Classrooms. Philadelphia: John Benjamins B. V.

Deci, E. L., \& Ryan, R. M. (1985). Intrinsic motivation and self-determination in human behavior. New York: Plenum.

Deci, E. L., \& Ryan, R. M. (2000). "The "what" and "why" of goal pursuits: Human needs and the self-determination of behaviour", in Psychological Inquiry, 11: 227-268.

Declaración de Helsinki (2008). World Medical Association http://www.wma.net/es/30publications/10policies/b3/, accessed 15 November 2016.

Duda, J. L., \& Nicholls, J. G. (1992). Dimensions of achievement motivation in schoolwork and sport. Journal of Educational Psychology, 84(3), 290-299.

Eurydice. (2006a). Content and language integrated learning (CLIL) at school in Europe. Sweden. Brussels: European Commission.

Eurydice. (2006b). Content and language integrated learning (CLIL) at school in Europe. The Netherlands. Brussels: European Commission.

Eurydice. (2008). Cifras clave de la enseñanza de lenguas en los centros escolares de Europa. Instituto de Formación del Profesorado Investigacin e Innovacin Educativa IFIIE.

Granero Gallegos, A., Baena Extremera, A., Pérez Quero, F.J., Ortíz Camacho, M.M., \& Bracho Amador, C. (2012). Analysis of motivational profiles of satisfaction and importance of physical education in high school adolescents. Journal of Sports Science \& Medicine, $11,614-623$.

Granero-Gallegos, A., \& Baena-Extremera, A. (2013). Análisis preliminar exploratorio del "Sport Motivation Scale" adaptado a la Educación Física. Espiral. Cuadernos del profesorado 6(12), 3-14.

Granero-Gallegos, A., Baena-Extremera, A., Pérez-Quero, F. J., Ortiz-Camacho, M. M., \& Bracho-Amador, C. (2014). Validación española del «intention to partake in leisure-time physical activity». Retos. Nuevas Tendencias en Educación Física, Deporte y Recreación, 26, 40-45.

Hewit, E. C., \& García-Sánchez, E. (2012). Evolución del Aprendizaje Integrado de Contenidos y Lengua (AICLE/CLIL) en España: Un Proyecto Empírico en la Universidad. Latin American Journal of Content Language Integrated Learning, 5(1), 57-67.

Howard, E. R., Sugarman, J., Christian, D., Lindhom-Leary, K., \& Rogers, D. (2007). Guiding Principles for Dual Language Education (Second ed.). Washington, DC: CAL.

Hunt, M. (2011). Learners' perceptions of their experiences of learning subject content through a foreign language. Educational Review, 63(3), 365-378.

Jäppinen, A. K. (2005). Thinking and content learning of mathematics and science as cognitional development in content and language integrated learning (CLIL). Language and Education, 19(2), 147-168.

Kirk, D. (2003). Physical education: a gendered history. In D. Penney (Ed.), Gender and Physical Education. Contemporary issues and future directions. London and New York: Routledge.

Kline, R. B. (2005). Principles and Practice of Structural Equation Modelling (2nd ed.). New York: The Guilford Press.

Lasagabaster, D. (2008). Foreign Language Competence in Content and Language Integrated Courses. The Open Applied Linguistics, 1, 30-41. 
E. Fernández Barrionuevo and A. Baena Extremera Motivation in Physical Education and Foreign...

Lasagabaster, D. (2011). English achievement and student motivation in CLIL and EFL settings. Innovation in Language Learning and Teaching, 5(1), 3-18.

Lorenzo, F. (2007). The sociolingüístics of CLIL: Language planning and language change in 21th century europe. Revista española de lingüistica aplicada, 1, 27-38.

Lorenzo, F., Casal, S., \& Moore, P. (2009). The Effects of Content and Language Integrated Learning in European Education: Key Findings from the Andalusian Bilingual Sections Evaluation Project. Applied linguistics, 31(3), 418-442.

McCall, I. (2011). Score in French: motivating boys with football in Key Stage 3. Language Learning Journal, 39(1), 5-18.

Mearns, T. L. (2012). Using, CLIL to enhance pupils' experience of learning and raise attainment in German and health education: a teacher research project. The Language Learning Journal, 40(2), 175-192.

Morales-Rodríguez, F. M. (2011). Aprendizaje, Motivación y Rendimiento en Estudiantes de Lengua Extranjera Inglesa. Psicología Educativa, 17(2), 195-207.

Moreno-Murcia, J. A., González-Cutre, D., \& Ruiz-Pérez, L. M. (2009). Self-Determined motivation and Physical Education importance. Human Movement, 10(1), 5-11.

Moreno-Murcia, J. A., Huescar, E., \& Cervello, E. (2012). Prediction of Adolescents doing Physical Activity after Completing Secondary Education. Spanish Journal of Psychology, 15(1), 90-100.

Moreno-Murcia, J. A., Peco, N., Huéscar, E., Alarcón, E., \& Crevelló, E. (2012). Desarrollo y validación de escalas para la medida de la comunicación en Educación Física y relación con la motivación intrínseca. Universitas Psychologica, 11(3), 957-967.

Nicholls, J. G., Cheung, P. C., Lauer, J., \& Patashnick, M. (1989). Individual differences in academic motivation: Perceived ability, goals, beliefs, and values. Learning and Individual Differences, 1(1), 63-84.

Noels, K. A., Clement, R., \& Pelletier, L. G. (1999). Perceptions of teachers' communicative style and students' intrinsic and extrinsic motivation. Modern Language Journal, 83(1), 23-34.

Noels, K. A., Pelletier, L. G., Clément, R., \& Vallerand, R. J. (2000). Why are you learning a second language? Motivational orientations and self-determination theory. Language learning, 50(1), 57-85.

Nunnally, J. C. \& Bernstein, I.H. (1994). Psychometric theory. New York: McGraw-Hill.

Nunnally, J. C. (1967). Psychometric Theory. New York: McGraw-Hill.

Orden de 28 de junio de 2011 por la que se regula la enseñanza bilingüe en los centros docentes de la Comunidad Autónoma de Andalucía. (B.O.J.A), Nº135 del 12 de junio de 2011).

Pae, T. I. (2008). Second language orientation and self-determination theory - A structural analysis of the factors affecting second language achievement. Journal of Language and Social Psychology, 27(1), 5-27.

Pelletier, L. G., Fortier, M. S., Vallerand, R. J., Tuson, K. M., Briere, N. M., \& Blais, M. R. (1995). Toward a new measure of intrinsic motivation, extrinsic motivation, and amotivation in sports: the Sport Motivation Scale (SMS). Journal of Sport and Exercise Psychology, $17,35-53$.

Pérez-Cañado, M. L. (2011). The effects of CLIL within the APPP: lessons learned and ways forward. In M. R. G. d. S. Crespo Jiménez, María Ángeles (Ed.), ESP teaching and methodology English studies in honour of Ángeles Linde López (Vol. 182, pp. 389-406). Granada: Universidad de Granada.

Pérez-Cañado, M. L. (2012). CLIL research in Europe: past, present, and future. International Journal of Bilingual Education and Bilingualism, 15(3), 315-341. 
Ruiz, P. J., Rodriguez, A., Armada, A. J., Cruz, E., Cruz, G., Dinos, C., \& Ydler, R. (2010). New York State Office of Bilingual Education and Foreign Language Studies TwoWay Bilingual Education Programs: A Resource Guide. New York: Office of Elementary, Middle, Secondary, and Continuing Education and Office of Higher Education Office of Bilingual Education and Foreign Language Studies.

Seikkula-Leino, J. (2007). CLIL Learning: Achievement Levels and Affective Factors. Language and Education, 21(4), 328-341.

Skutnabb-Kangas, T., \& Dunbar, R. (2010). Indigenous Children's Education as Linguistic Genocide and a Crime Against Humanity? A Global View. Kautokeino: Gáldu - Resource Centre for the Rights of Indigenous Peoples.

Skutnabb-Kangas, T., \& McCarty, T. L. (2008). Key concepts in bilingual education:ideological, historical, epistemological, and empirical fundations. In J. Cummins \& N. Hornberger (Eds.), Encyclopedia of language and education (2nd edition ed., Vol. 5, pp. 3-17). New York: Springer.

Valero, N., \& Jiménez-Fernández, G. (2015). Estudio exploratorio sobre las dificultades en el aprendizaje de una segunda lengua: la opinión del profesorado. Espiral. Cuadernos del profesorado $8(16)$, 3-12.

Vallerand, R. J., Blais, M. R., Brière, N. M., \& Pelletier, L. G. (1989). Construction et validation de l'échelle de motivation en éducation (EME). (C. P. Association, Ed.) Canadian Journal of Behavioural Science/Revue canadienne des sciences du comportement, 21 (3), 323-349.

Vallerand, R. J., Pelletier, L. G., Blais, M. R., Brière, N. M., Senécal, C., \& Vallières, E. F. (1992). The Academic Motivation Scale: A measure of intrinsic, extinsic, and amotivation in education. Educational and Psychological Measurement, 52(4), 1003-1017.

Wang, C. K. J., \& Biddle, S. J. H. (2001). Young people's motivational profiles in physical activity: A cluster analysis. Journal of Sport \& Exercise Psychology, 23(1), 1-22.

Williams, M., Burden, R., \& Lanvers, U. (2002). 'French is the language of love and stuff': Student perceptions of issues related to motivation in learning a foreign language. British Educational Research Journal, 28(4), 503-528. 